\title{
In Vitro Anti-Inflammatory Activity of Morus alba L. Stem Extract in LPS-Stimulated RAW 264.7 Cells
}

\author{
Nattaporn Soonthornsit, ${ }^{1}$ Chetsadaporn Pitaksutheepong, ${ }^{2}$ Warinkarn Hemstapat, ${ }^{3}$ \\ Pongsak Utaisincharoen, ${ }^{4}$ and Tasana Pitaksuteepong ${ }^{1}$ \\ ${ }^{1}$ Department of Pharmaceutical Technology, Faculty of Pharmaceutical Sciences and Center of Excellence for Innovation in Chemistry, \\ Naresuan University, Tha Pho, Mueang Phitsanulok, Phitsanulok 65000, Thailand \\ ${ }^{2}$ Food Biotechnology Research Unit, National Center for Genetic Engineering and Biotechnology (BIOTEC), 113 Thailand Science Park, \\ Phahonyothin Road, Khlong Nueng, Khlong Luang, Pathum Thani 12120, Thailand \\ ${ }^{3}$ Department of Pharmacology, Faculty of Science, Mahidol University, Rama VI Road, Ratchathewi, Bangkok 10400, Thailand \\ ${ }^{4}$ Department of Microbiology, Faculty of Science, Mahidol University, Rama VI Road, Ratchathewi, Bangkok 10400, Thailand
}

Correspondence should be addressed to Tasana Pitaksuteepong; tasanap@nu.ac.th

Received 8 February 2017; Revised 9 April 2017; Accepted 16 May 2017; Published 8 June 2017

Academic Editor: Cheorl-Ho Kim

Copyright (C) 2017 Nattaporn Soonthornsit et al. This is an open access article distributed under the Creative Commons Attribution License, which permits unrestricted use, distribution, and reproduction in any medium, provided the original work is properly cited.

\begin{abstract}
Morus alba L., also known as white mulberry or Mhon, has long been used in traditional medicines. This study was aimed to investigate anti-inflammatory activities of mulberry stem ethanolic extract (MSE) in lipopolysaccharide- (LPS-) stimulated RAW 264.7 macrophage cell line. The MSE was first prepared and then investigated for cell viability using the MTT assay. The antiinflammatory activities were investigated through the inhibition of inducible nitric oxide synthase (iNOS), cyclooxygenase- (COX-) 2 mRNA expression, and iNOS protein expression using reverse transcription-polymerase chain reaction (RT-PCR) assay and immunoblotting analysis, respectively. The inhibition of nitric oxide production of the MSE was also investigated using the Griess reaction assay. The MSE concentration ranging from 10 to $40 \mu \mathrm{g} / \mathrm{ml}$ yielded cell viability higher than $80 \%$. The MSE at concentrations of 20 and $40 \mu \mathrm{g} / \mathrm{ml}$ demonstrated anti-inflammatory activity through the inhibition of nitric oxide production via suppression of both the iNOS mRNA and protein. It was also found to inhibit the expression of COX-2 mRNA in LPS-induced RAW 264.7 cells. This study is the first to report the anti-inflammatory potential of the extract prepared from the stem of mulberry.
\end{abstract}

\section{Introduction}

Morus alba (Moraceae) is known as mulberry or Mhon in Thai. Its leaves, fruit, and bark have long been used in traditional Chinese medicine to treat fever, improve eyesight, strengthen joints, and lower blood pressure [1]. The leaves are the most widely used and are consumed as an antihyperglycemic supplement in Korea and Japan [1]. Cultivation of mulberry trees in Thailand is also widespread, particularly for the leaves to feed silkworms. The twigs and stems are often pruned, cut as normal cultivation practice, and used for firewood but are rarely used for other purposes, such as medicinal use.

A natural chemical compound found in the twigs and stems of mulberry trees is oxyresveratrol or trans-2, $3^{\prime}, 4$, $5^{\prime}$-tetrahydroxystilbene. This compound has been reported to possess antioxidative and radical scavenging activities with $\mathrm{IC}_{50}$ value of $3.6 \pm 0.0 \mu \mathrm{M}$ and $15.1 \pm 2.3 \mu \mathrm{M}$ using $\mathrm{FeSO}_{4} / \mathrm{H}_{2} \mathrm{O}_{2}$-induced lipid peroxidation in rat liver microsomes and DPPH assay, respectively [2]. It has also been reported to have anti-inflammatory activity by inhibiting the production of nitrite, prostaglandin $\mathrm{E}_{2}$, and inducible nitric oxide synthase (iNOS) expression in the LPS-activated RAW 264.7 macrophage cells through the NF- $\kappa$ B activation pathway [2]. In addition, oxyresveratrol has been shown to inhibit the rat paw edema induced by carrageenan in a dose-dependent manner [2]. Apart from the NF- $\kappa$ B signaling pathway, the anti-inflammatory effect of oxyresveratrol in LPS-induced RAW264.7 cells has recently been reported as also occurring through the inhibition of the mitogenactivated protein kinase (MAPK) pathway [3]. 
Our previous study [4] found different amounts of oxyresveratrol in various parts of the mulberry tree, and the ethanolic extract obtained from the mulberry stems has the highest amount of oxyresveratrol compared to that obtained from the twigs, with the least amount in the leaves. Therefore, we hypothesized that the stem wood of mulberry trees, which was left unused, would also have anti-inflammatory activity.

Inflammation is the body's protective response that intended to eliminate the initial cause of cell injury. However, sometimes, it can also become self-perpetuating and cause further inflammation. Chronic inflammation is involved in many diseases, for example, ulcerative colitis, Alzheimer's, dermatitis, cardiovascular diseases, cancer, inflammatory bowel disease (IBD), systemic lupus erythematous (SLE), osteoarthritis (OA), and rheumatoid arthritis (RA) [5]. Once macrophages are elicited, inflammatory mediators including nitric oxide and proinflammatory mediators such as iNOS and COX-2 are produced. There are few reports $[1,6]$ on the anti-inflammatory effect of the stems of mulberry trees. Therefore, this study was aimed to investigate the antiinflammatory activities of mulberry stem extract (the MSE) through the inhibition of iNOS and COX-2 expression and NO production in LPS-stimulated RAW 264.7 macrophage cells.

\section{Materials and Methods}

2.1. Materials. Oxyresveratrol, isolated and purified from Artocarpus lakoocha heartwood or Puag-Haad, was prepared in-house using the method as previously described [7]. HPLC grade acetonitrile was purchased from RCI Labscan (Bangkok, Thailand). A mouse macrophage cell line (RAW 264.7) was obtained from the American Type Culture Collection (ATCC \#TIB-71, Manassas, Virginia, USA). Lipopolysaccharide (LPS), 3-(4, 5-dimethylthiazol-2-yl)-2, 5diphenyltetrazolium bromide (MTT), and dimethylsulfoxide (DMSO) were purchased from Sigma-Aldrich (Saint Louis, Missouri, USA). RNAspin Mini RNA Isolation Kit was purchased from GE Healthcare (Buckinghamshire, UK). iScript $^{\mathrm{TM}} \mathrm{cDNA}$ Synthesis Kit was purchased from Bio-Rad Laboratories (Hercules, California, USA). dNTPs were purchased from Fermentas (Vilnius, Lithuania). Taq DNA polymerase was purchased from Invitrogen (California, USA). Griess Reagent Kit was purchased from Molecular Probes, Inc. (Eugene, Oregon, USA). Dulbecco's modified Eagle's medium (DMEM) and fetal bovine serum (FBS) were purchased from HyClone (Logan, Utah, USA). L-Glutamine was purchased from Biological Industries (Kibbutz Beit Haemek, Israel). Blocking solution was purchased from Roche Diagnostics (Mannheim, Germany). Specific monoclonal rabbit antibody to mouse iNOS was purchased from Santa Cruz Biotechnology (Santa Cruz, California, USA). Specific monoclonal mouse antibody to $\beta$-actin was purchased from R\&D systems (Minnesota, USA). Horseradish peroxidase- (HRP-) conjugated goat anti-rabbit IgG and HRP-conjugated rabbit anti-mouse IgG were purchased from Pierce (Rockford, Illinois, USA).
2.2. Preparation of the MSE. Fresh mulberry stems (var. Buriram 60) were supplied by the Queen Sirikit Sericulture Center, Tak Province, Thailand. A voucher specimen was verified by Dr. Pranee Nangngam and deposited at the Faculty of Science, Naresuan University (voucher specimen number 004067). The chopped and dried inner wood of the mulberry stems $(3,700 \mathrm{~g})$ was macerated in $4 \mathrm{~L}$ of $80 \%$ ethanol. After filtration, the filtrate was evaporated under reduced pressure using a rotary evaporator (Buchi Rotavapor R-114, Flawil, Switzerland) and continued drying using a water bath (M25 Lauda, Deutschland, Germany). The percentage yield of the extract was calculated using the following equation:

$$
\begin{aligned}
\% \text { yield }= & \left(\frac{\text { Dried weight of crude extract }}{\text { Dried weight of chopped-dried plant }}\right) \\
& \times 100 .
\end{aligned}
$$

2.3. High Performance Liquid Chromatography (HPLC) Analysis of Oxyresveratrol in the MSE. Oxyresveratrol was used as the marker compound for the quantitative HPLC analysis of MSE using the method described by Yhirayha [7]. Standard stock solution $1 \mathrm{mg} / \mathrm{ml}$ of oxyresveratrol was prepared by dissolving in $80 \%$ ethanol. The stock solution was further diluted to 5 standard working solutions over the concentrations range of 0.0005 to $0.05 \mathrm{mg} / \mathrm{ml}$ using $80 \%$ ethanol. An HPLC system (LC-20AT, Shimadzu, Kyoto, Japan), equipped with a UVVis detector (SPD-20A, Shimadzu, Japan), an autosampler (SIL-10ADVP, Shimadzu, Kyoto, Japan), and a column oven, was used. Analysis was performed on a C18 boned-silica gel column (Gemini, $5 \mathrm{u}, 150 \times 4.6 \mathrm{~mm}$, Phenomenex, Torrance, USA) in the isocratic mode. Acetonitrile mixed with $0.05 \mathrm{M}$ phosphate buffer $\mathrm{pH} 3$ (13 ratio) was used as the mobile phase at a flow rate of $1 \mathrm{ml} / \mathrm{min}$. UV detector wavelength of $320 \mathrm{~nm}$ with column oven temperature of $30^{\circ} \mathrm{C}$ was set. The injection volume was $20 \mu \mathrm{l}$. Run time was set at $13 \mathrm{~min}$. The stock solution of the extract was prepared in $80 \%$ ethanol at concentration of $0.25 \mathrm{mg} / \mathrm{ml}$.

2.4. Thin Layer Chromatography (TLC) Analysis. The stock solutions of the crude extract and oxyresveratrol were prepared by dissolving in ethanol at concentration $6 \mathrm{mg} / \mathrm{ml}$ and $1 \mathrm{mg} / \mathrm{ml}$, respectively. Ascending TLC analysis was performed using silica gel $60 \mathrm{~F}_{254}$ (Merck, Darmstadt, Germany) as a stationary phase and methanol : chloroform $(15: 85 \% \mathrm{v} / \mathrm{v})$ as a mobile phase. Small amount of samples was spotted at about $0.5 \mathrm{~cm}$ from the bottom of the TLC plate and then placed in the chamber which was left to saturate with solvent vapor for $15 \mathrm{~min}$. The developing time was allowed for $5 \mathrm{~min}$. After that, the plate was removed from the chamber and air-dried. The TLC spots were viewed under UV light at 254 and $366 \mathrm{~nm}$. Then, anisaldehyde reagent was sprayed on TLC plate and then heated continuously to $100^{\circ} \mathrm{C}$ in order to visualize oxyresveratrol. The colored spots appeared were marked and the retention factor $\left(R_{f}\right)$ was calculated from the following equation:

$$
R_{f}=\frac{\text { distance traveled by a compound }}{\text { distance traveled by solvent front }} .
$$


TABLE 1: The primer sequences used for PCR amplification.

\begin{tabular}{|c|c|c|c|c|c|}
\hline Gene & Primer sequence $\left(5^{\prime}-3^{\prime}\right)$ & Product size (bp) & \multicolumn{2}{|c|}{ PCR condition } & Reference \\
\hline \multirow{3}{*}{ iNOS } & \multirow{3}{*}{$\begin{array}{l}\text { GCA GAA TGT GAC CAT CAT GG } \\
\text { ACA ACC TTG GTG TTG AAG GC }\end{array}$} & \multirow{3}{*}{414} & $94^{\circ} \mathrm{C}, 5 \mathrm{~min}$ & \multirow{3}{*}{30 cycles } & \multirow{3}{*}[8]{} \\
\hline & & & $\begin{array}{l}94^{\circ} \mathrm{C}, 45 \mathrm{sec} \\
60^{\circ} \mathrm{C}, 1 \mathrm{~min}\end{array}$ & & \\
\hline & & & $72^{\circ} \mathrm{C}, 1 \mathrm{~min}$ & & \\
\hline \multirow{4}{*}{ COX -2} & \multirow{4}{*}{$\begin{array}{l}\text { AGA AGG AAA TGG CTG CAG AA } \\
\text { GCT CGG CTT CCA GTA TTG AG }\end{array}$} & \multirow{4}{*}{194} & $94^{\circ} \mathrm{C}, 5 \mathrm{~min}$ & \multirow{4}{*}{30 cycles } & \multirow{4}{*}{ This study } \\
\hline & & & $94^{\circ} \mathrm{C}, 30 \mathrm{sec}$ & & \\
\hline & & & $54^{\circ} \mathrm{C}, 30 \mathrm{sec}$ & & \\
\hline & & & $72^{\circ} \mathrm{C}, 30 \mathrm{sec}$ & & \\
\hline \multirow{4}{*}{$\beta$-Actin } & \multirow{4}{*}{$\begin{array}{l}\text { CCA GAG CAA GAG AGG TAT CC } \\
\text { CTG TGG TGG TGA AGC TGT AG }\end{array}$} & \multirow{4}{*}{436} & $94^{\circ} \mathrm{C}, 5 \mathrm{~min}$ & \multirow{4}{*}{30 cycles } & \multirow{4}{*}[8]{} \\
\hline & & & $94^{\circ} \mathrm{C}, 45 \mathrm{sec}$ & & \\
\hline & & & $58^{\circ} \mathrm{C}, 1 \mathrm{~min}$ & & \\
\hline & & & $72^{\circ} \mathrm{C}, 1 \mathrm{~min}$ & & \\
\hline
\end{tabular}

\subsection{Anti-Inflammatory Activity of the MSE}

2.5.1. Sample Preparation. The dried crude extract was dissolved in $0.5 \%$ DMSO to make a final concentration of $1 \mathrm{mg} / \mathrm{ml}$ and then filtered through $0.22 \mu \mathrm{m}$ nylon membrane (VertiClean $^{\mathrm{TM}}$, Vertical Chromatography Co., Ltd., Bangkok, Thailand) before further analysis. Oxyresveratrol, a biological marker in this study, was also prepared in the same manner as the extract.

2.5.2. Cell Culture and Viability. The RAW 264.7 cells were cultured in DMEM supplemented with 10\% FBS and 1\% Lglutamine and incubated at $37^{\circ} \mathrm{C}$ in $5 \% \mathrm{CO}_{2}$. To determine cell viability, RAW 264.7 cells were seeded in a 96-well plate at a density of $3 \times 10^{4}$ cells/well. After overnight incubation, the cells were treated with various concentrations of samples in the presence of $100 \mathrm{ng} / \mathrm{ml}$ LPS and incubated for $24 \mathrm{~h}$. Cell viability was determined by MTT assay.

2.5.3. Reverse Transcription-Polymerase Chain Reaction (RTPCR) Assay. RAW 264.7 cells were seeded in a 6-well plate at a concentration of $2.5 \times 10^{5}$ cells $/ \mathrm{ml}$. After overnight incubation, the cells were resuspended in $1 \mathrm{ml}$ of supplemented DMEM and pretreated with various concentrations of samples for $2 \mathrm{~h}$. LPS $100 \mathrm{ng} / \mathrm{ml}$ was then added and further incubated for $6 \mathrm{~h}$. The cells were then washed twice with $1 \mathrm{ml}$ PBS, harvested in $1 \mathrm{ml}$ PBS, and subjected to RT-PCR analysis. Total RNA from the stimulated cells was extracted using RNAspin Mini RNA Isolation Kit according to the manufacturer's instruction. cDNA was synthesized using iScript cDNA Synthesis Kit. The TGradient thermal cycler 96 (Biometra, Goettingen, Germany) was used for PCR amplification. The PCR mixture contained 50 ng cDNA, 1x PCR buffer, $1.25 \mathrm{mM} \mathrm{MgCl}_{2}, 100 \mu \mathrm{M}$ dNTPs, $450 \mathrm{nM}$ of each primer, and $1 \mathrm{U}$ Taq polymerase. The primers and PCR conditions used for amplification of iNOS, COX-2, and $\beta$ actin genes are shown in Table 1 . The amplified products were separated on $1.5 \%(\mathrm{w} / \mathrm{v})$ agarose gel. After gel electrophoresis was completed, the gels were stained with ethidium bromide and the PCR products were visualized under an UV illuminator (GeneSys, Rochester, New York, USA). The band intensity of iNOS and COX-2 genes was then normalized to $\beta$-actin and calculated as the relative expression.

2.5.4. Immunoblotting Analysis. RAW 264.7 cells were seeded in a 6-well plate at a concentration of $1.9 \times 10^{5}$ cells $/ \mathrm{ml}$. After overnight incubation, they were resuspended in $1 \mathrm{ml}$ of supplemented DMEM and pretreated with various concentrations of samples for $2 \mathrm{~h}$ before LPS $(100 \mathrm{ng} / \mathrm{ml})$ was added. After $16 \mathrm{~h}$ of incubation, the cell supernatants were collected and subjected to NO production analysis (see Section 2.5.5). The cells were washed twice with PBS and resuspended in $1 \mathrm{ml}$ PBS. Following centrifugation of the cell sample at $10,000 \mathrm{rpm}$, the cell pellet was lysed in lysis buffer, $\mathrm{pH}$ 6.8. The mixtures were sonicated on ice for $1 \mathrm{~min}$ and then heated for $5 \mathrm{~min}$ in a dry bath incubator (Boekel Scientific, Pennsylvania, USA). The mixture was centrifuged at $10,000 \mathrm{rpm}$ at $4^{\circ} \mathrm{C}$ for $5 \mathrm{~min}$. The cell lysates were electrophoresed on $8 \%$ SDS-PAGE and then electrotransferred to a nitrocellulose membrane. The membrane was blocked with $5 \%$ blocking solution (Roche Diagnostics, Mannheim, Germany) in PBS for $1 \mathrm{~h}$ before incubating at $4^{\circ} \mathrm{C}$ overnight with specific monoclonal rabbit antibody to mouse iNOS and specific monoclonal mouse antibody to $\beta$-actin. The concentration of each antibody was used according to the manufacturer's recommendation. The membranes were washed 3 times with $0.1 \%$ Tween 20 in PBS for $15 \mathrm{~min}$, followed by reacting with HRP-conjugated goat anti-rabbit IgG (for iNOS) and HRP-conjugated rabbit anti-mouse IgG (for $\beta$-actin) at room temperature for $1 \mathrm{~h}$. After that, the membrane was washed 4 times (20 min each wash) with $0.1 \%$ Tween 20 in PBS. Protein bands were detected by enhanced chemiluminescence as recommended by the manufacturer (Roche Diagnostics, Mannheim, Germany) after exposure 
to hyperfilm (GE Healthcare, Buckinghamshire, UK). The iNOS immunoblot signals were compared with $\beta$-actin and calculated as the relative protein expression.

2.5.5. NO Production Assay. As detailed above, the nitrite concentration in cell supernatant was measured as an indicator of NO production using the Griess Reagent Kit. Briefly, $150 \mu \mathrm{l}$ of each supernatant was mixed with $20 \mu \mathrm{l}$ of Griess reagent $(1 \%$ sulfanilamide in $5 \%$ phosphoric and $0.1 \%$ naphthylethylenediamine dihydrochloride in water) and $130 \mu \mathrm{l}$ of distilled water in a 96-well plate. The mixtures were incubated at room temperature for $30 \mathrm{~min}$ and then the absorbance of each well was determined at $548 \mathrm{~nm}$ using a microplate reader. The amount of nitrite in samples was back-calculated from a sodium nitrite calibration curve $(0-100 \mu \mathrm{M})$.

2.6. Statistical Analysis. All data were expressed as mean \pm standard deviation (SD). Results were obtained from at least three independent experiments, each performed in triplicate. Statistical analysis was determined using one-way analysis of variance (ANOVA) followed by the Tukey's test for multiple comparisons (GraphPad Prism 6.0, GraphPad Software Inc., San Diego, USA). $P$ values less than or equal to 0.05 were considered significant.

\section{Results and Discussion}

The leaves, fruit, and bark of mulberry have long been used to treat various illnesses and to improve health functions. However, few reports have investigated the health benefits of the stem wood of mulberry which is abundantly available in Thailand. The anti-inflammatory effects were the biological activity particularly investigated in this study.

3.1. HPLC Analysis of Oxyresveratrol in the MSE. First, the MSE was prepared. Ethanolic extract was obtained as a powder, which had a dark brown color, with a percentage yield of $5.13 \%$ of the raw woody material. The amount of oxyresveratrol in the MSE was analyzed by HPLC. The calculated amount of oxyresveratrol in the MSE was $17.87 \pm$ $0.61 \%$ [9].

3.2. TLC Analysis. TLC analysis was performed to conduct quality control of natural herbal product containing complex mixtures of compounds like in the case of mulberry stem extract. Oxyresveratrol, one of the bioactive compounds found in mulberry stem extract, was used as a marker. Observing under UV light at $254 \mathrm{~nm}$ and $366 \mathrm{~nm}$, the results showed that mulberry stem extract showed eight spots with $R_{f}$ values $0.02,0.09,0.16,0.44,0.64,0.71,0.78$, and 0.87 , while oxyresveratrol showed only clear one spot with $R_{f}$ value 0.44 by comparing $R_{f}$ value. It was clearly shown that a reddish spot observed in mulberry stem extract after spraying TLC plate with anisaldehyde reagent with $R_{f}$ value of 0.44 was oxyresveratrol (Figure 1).

3.3. Cell Viability. To ensure that the cells were healthy before performing the bioactivity assays and the tested concentrations were not toxic to the cells, cell viability after treatment

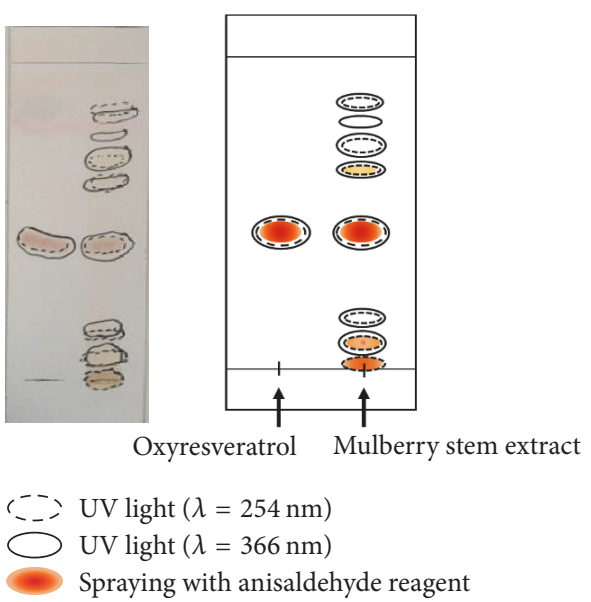

Figure 1: TLC fingerprint of mulberry stem extract. Standard oxyresveratrol was used as a marker. Mobile phase system was methanol : chloroform $(15: 85 \% \mathrm{v} / \mathrm{v})$.

with various concentrations of the MSE was determined. The concentrations of the MSE that yielded cell viability higher than $80 \%$ were the main aim of this experiment. The RAW 264.7 cell viability slightly decreased with increasing the concentration of the MSE from 10 to $150 \mu \mathrm{g} / \mathrm{ml}$ (Figure 2). Identifying the concentrations of the MSE that yielded cell viability higher than $80 \%$, it was found to be in the range of 10 to $40 \mu \mathrm{g} / \mathrm{ml}$ and the concentrations of the MSE selected for subsequent studies were 20 and $40 \mu \mathrm{g} / \mathrm{ml}$. Oxyresveratrol was included in this study as the marker of the MSE. An equivalent amount of oxyresveratrol in each concentration of the extract tested (for example, equivalent amount of oxyresveratrol in the extract $100 \mu \mathrm{g} / \mathrm{ml}$ was $17 \mu \mathrm{g} / \mathrm{ml}$ ) was also evaluated for the effect on cell viability. The results were shown to be similar to those observed in the MSEtreated cells (Figure 2). The anti-inflammatory effects of oxyresveratrol were also confirmed in subsequent studies, in which the selected concentrations of oxyresveratrol were 5 and $10 \mu \mathrm{g} / \mathrm{ml}$.

3.4. Anti-Inflammatory Activity of the MSE. M. alba extract has been demonstrated to exhibit anti-inflammatory activity, through the inhibition of iNOS, NO, and COX [10-15]. However, most of the extract tested was prepared from leaves $[10,11,14]$ and root bark $[12,13,15]$. In our study, antiinflammation activity of the extract prepared from mulberry stems was investigated.

In an LPS-stimulated mouse macrophage RAW 264.7 cells model, the NF- $\kappa \mathrm{B}$ signaling pathway plays a crucial role in regulating inflammation through the transcription of iNOS, COX, and cytokine genes. Found in the cytoplasm of resting cells, dimer NF- $\kappa \mathrm{B}$ is normally confined to an inactive cytoplasmic complex through binding to an inhibitory protein, $\mathrm{I}-\kappa \mathrm{B}$, which masks its nuclear localization signal. Exposure of cells to external proinflammatory stimuli such as mitogens, inflammatory cytokines, and LPS causes rapid $\mathrm{I}-\kappa \mathrm{B}$ phosphorylation by $\mathrm{I}-\kappa \mathrm{B}$ kinase (IKK), resulting in free and subsequent nuclear translocation of NF- $\kappa \mathrm{B}[16$, 


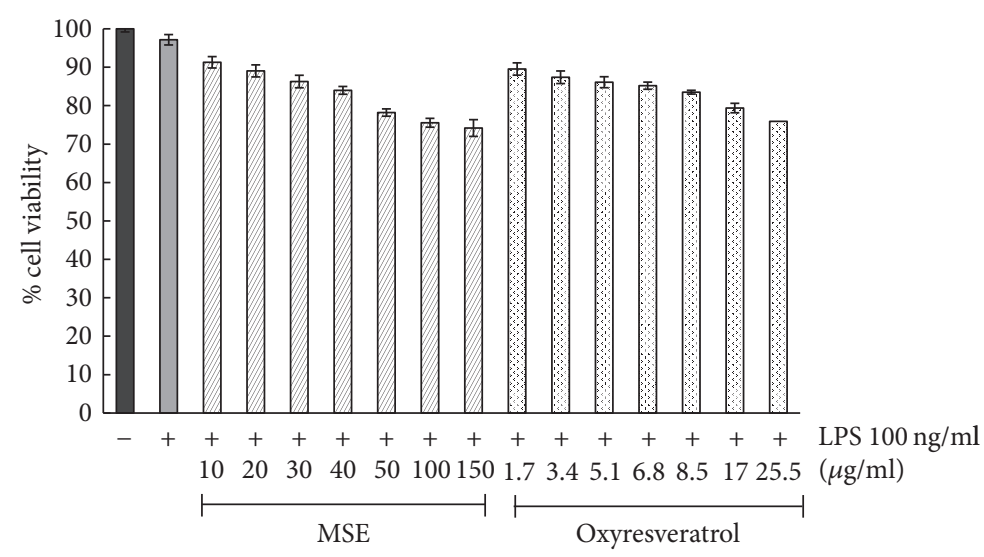

FIGURE 2: The percentage viability of RAW 264.7 cells which was untreated (negative control), treated with only $100 \mathrm{ng} / \mathrm{ml}$ LPS (positive control), and treated with various concentrations of MSE and oxyresveratrol in the presence of $100 \mathrm{ng} / \mathrm{ml}$ LPS for $24 \mathrm{~h}$. The viability of cells was determined by MTT assay. The data were represented as means \pm SD of three independent experiments.

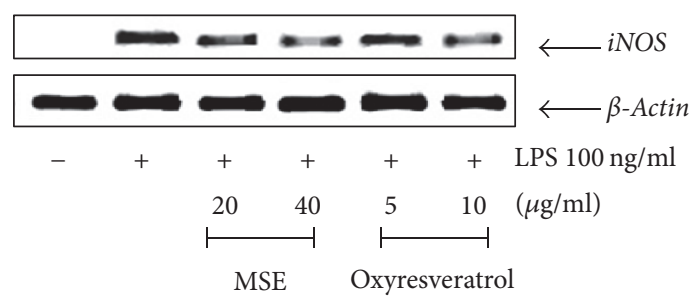

(a)

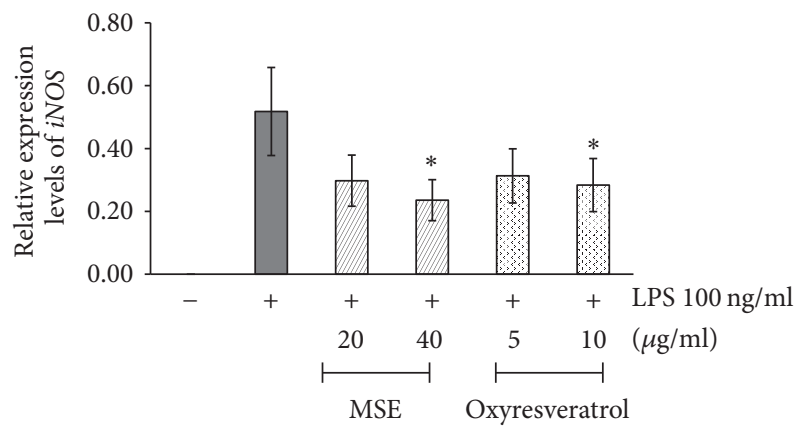

(b)

FIGURE 3: The effects of MSE and oxyresveratrol on the expression of iNOS mRNA in RAW 264.7 cells. The untreated cells were used as a negative control and the cells treated with only $100 \mathrm{ng} / \mathrm{ml}$ LPS were served as a positive control. (a) RT-PCR analysis for detection of iNOS mRNA expression in LPS-stimulated RAW 264.7 cells which were pretreated with MSE at the concentrations of 20 and $40 \mu \mathrm{g} / \mathrm{ml}$ or oxyresveratrol at the concentrations 5 and $10 \mu \mathrm{g} / \mathrm{ml}$ for $2 \mathrm{~h}$. (b) The relative expression of iNOS mRNA compared to $\beta$-actin. The data were represented as means \pm SD of three independent experiments. The means marked with $*$ are significantly different $(P<0.05)$ from that of the cells treated with only LPS.

17]. In the nucleus, $N F-\kappa B$ induces the transcription of a large variety of target proinflammatory genes including iNOS and COX-2. iNOS then further facilitates the conversion of L-arginine to L-citrulline and a large amount of NO, while COX-2 catalyzes the conversion of arachidonic acid to prostaglandins. Prostaglandins (PGs), especially $\mathrm{PGE}_{2}$ and $\mathrm{PGI}_{2}$, cause vasodilation that contribute to the vascular signs of inflammation and potentiate edema formation $[18,19]$.

3.4.1. Effect of the MSE on the Expression of iNOS mRNA and Protein. The anti-inflammatory effects of the MSE at the concentrations of 20 and $40 \mu \mathrm{g} / \mathrm{ml}$ were investigated through the inhibition on the expression of iNOS mRNA and its protein as well as the production of NO. Oxyresveratrol (marker) at the concentrations of 5 and $10 \mu \mathrm{g} / \mathrm{ml}$ was also tested. $\beta$-Actin was used as an internal standard for RT-PCR assay. As expected, the expression of iNOS mRNA and its protein was detected by stimulating RAW 264.7 cells with LPS (Figures 3 and 4). The expression level of iNOS in cells treated with the MSE at the concentration of $40 \mu \mathrm{g} / \mathrm{ml}$ was decreased by $50 \%$ compared with that in cells treated with LPS alone (Figure 3). Similar results were observed in cells treated with oxyresveratrol.

Western blotting was further performed to confirm the effects of the MSE on iNOS protein expression. The results showed that iNOS protein was significantly decreased in untreated RAW 264.7 cells comparing with LPS-treated RAW 264.7 cells (Figure 4). Therefore, the validity of the iNOS protein assay was again confirmed. The MSE at the concentrations of $20(P<0.05)$ and $40(P<0.001) \mu \mathrm{g} / \mathrm{ml}$ and oxyresveratrol at $10(P<0.05) \mu \mathrm{g} / \mathrm{ml}$ significantly inhibited the expression of iNOS protein compared with the cells treated only with LPS.

3.4.2. Effect of the MSE on NO Production. The inducible forms of NOS are the most important proinflammatory enzymes responsible for increasing the levels of NO. Therefore, the effect of tested compounds on the inhibition of $\mathrm{NO}$ production was further investigated. However, NO in the biological matrix is very unstable and rapidly oxidizes 


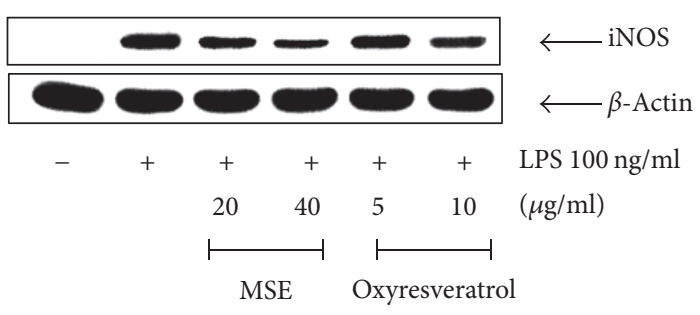

(a)

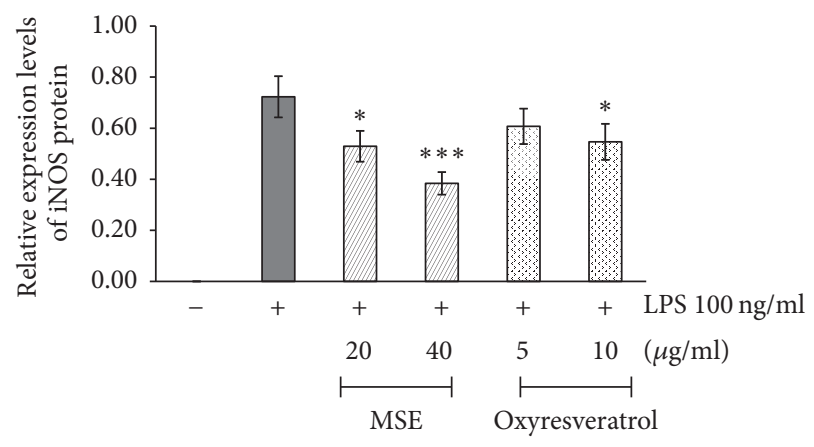

(b)

FIGURE 4: The effects of MSE and oxyresveratrol on the expression of iNOS protein in RAW 264.7 cells. The untreated cells were used as a negative control and the cells treated with only $100 \mathrm{ng} / \mathrm{ml}$ LPS served as a positive control. (a) Immunoblotting analysis for determination the expression of iNOS protein in LPS-stimulated RAW 264.7 cells which were pretreated with MSE at the concentrations of 20 and $40 \mu \mathrm{g} / \mathrm{ml}$ or oxyresveratrol at the concentrations 5 and $10 \mu \mathrm{g} / \mathrm{ml}$ for $2 \mathrm{~h}$. (b) The relative expression of iNOS protein compared to $\beta$-actin. The data were represented as means \pm SD of three independent experiments. The means marked with $*, * * *$ are significantly different $(P<0.05)$ and $(P<0.001)$, respectively, from that of the cells treated with only LPS.

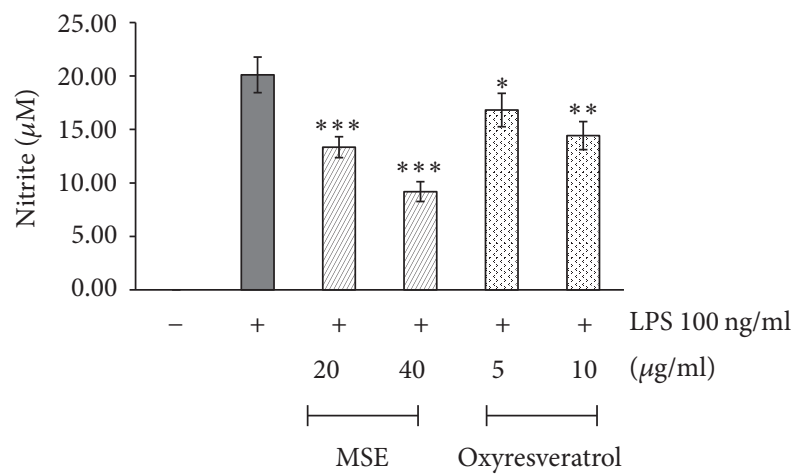

Figure 5: The effects of MSE and oxyresveratrol on the production of nitrite in LPS-stimulated RAW 264.7 cells which were untreated (negative control), treated with only $100 \mathrm{ng} / \mathrm{ml} \mathrm{LPS} \mathrm{(positive} \mathrm{con-}$ trol), pretreated with MSE at the concentrations of 20 and $40 \mu \mathrm{g} / \mathrm{ml}$ or oxyresveratrol at the concentrations of 5 and $10 \mu \mathrm{g} / \mathrm{ml}$ for $2 \mathrm{~h}$, and then treated with $100 \mathrm{ng} / \mathrm{ml}$ LPS for $16 \mathrm{~h}$. The supernatant was collected and determined by Griess reaction assay. The data were represented as means \pm SD of three independent experiments. The means marked with $*, * *, * * *$ are significantly different $(P<0.05)$, $(P<0.005)$, and $(P<0.001)$, respectively, from that of the cells treated with only LPS.

to nitrite $\left(\mathrm{NO}_{2}{ }^{-}\right)$and thus the measurement of nitrite is routinely used as an index of NO production.

For the untreated RAW 264.7 cells, the concentration of nitrite could not be detected (Figure 5). Once the cells were stimulated with LPS, a high concentration of nitrite was produced. The MSE at concentrations of 20 and $40 \mu \mathrm{g} / \mathrm{ml}$ were shown to inhibit nitrite production by $34 \%$ and $54 \%$, respectively, and oxyresveratrol at concentrations of 5 and $10 \mu \mathrm{g} / \mathrm{ml}$ was able to inhibit nitrite production by $16 \%$ and $28 \%$, respectively (Figure 5).

3.4.3. Effect of the MSE on COX-2 mRNA Expression. As shown in Figure 6, the MSE was able to inhibit the expression of COX-2 mRNA in LPS-activated RAW 264.7 cells. The inhibitory activity of the MSE at $40 \mu \mathrm{g} / \mathrm{ml}$ was shown to be higher than that of the MSE at $20 \mu \mathrm{g} / \mathrm{ml}$. The expression level of COX-2 mRNA in cells treated with the MSE at $40 \mu \mathrm{g} / \mathrm{ml}$ decreased by $70 \%$, compared with that in cells treated with LPS alone. Similar results were observed when LPS-activated RAW 264.7 cells were incubated with oxyresveratrol.

The results observed in this study clearly showed that the MSE could inhibit NO production, through the inhibition of both iNOS mRNA and protein expression. In addition, the extract was shown to suppress the expression of COX2 mRNA in LPS-stimulated RAW 264.7 cells. The inhibition effect on production of iNOS, COX-2, and NO of the MSE at $40 \mu \mathrm{g} / \mathrm{ml}$ was found to be higher than that of the MSE at $20 \mu \mathrm{g} / \mathrm{ml}$. The MSE showed more potent inhibitory effects than oxyresveratrol at an equivalent amount of oxyresveratrol (the MSE at $40 \mu \mathrm{g} / \mathrm{ml}$ equivalent to $6.8 \mu \mathrm{g} / \mathrm{ml}$ ). It has been recently reported that the stems of $M$. alba contained flavonoids (morusin), stilbenoids (mulberroside, resveratrol, and oxyresveratrol), and coumarins [1]. These polyphenols were shown to possess anti-inflammatory effects [20-22]. We also determined the amounts of total phenolic of the extract and it was $34.87 \pm 1.12 \mu \mathrm{mol} \mathrm{GAE} / \mathrm{mg}$ extract. Therefore, these polyphenols, other than oxyresveratrol, may explain the superior anti-inflammatory effect of the MSE. Although the precise molecular mechanisms responsible for the antiinflammatory activities of the MSE cannot be explained in the present study, oxyresveratrol which is an active component presented in the extract has been reported to exhibit its antiinflammatory effect via the inhibition of the NF- $\kappa \mathrm{B}$ and the MAPK pathways $[2,3]$. However, further elucidation of the insight mechanisms involved the anti-inflammatory effect of this plant extract is required.

\section{Conclusions}

This study is the first to demonstrate the potential antiinflammatory effects of the extract prepared from mulberry 


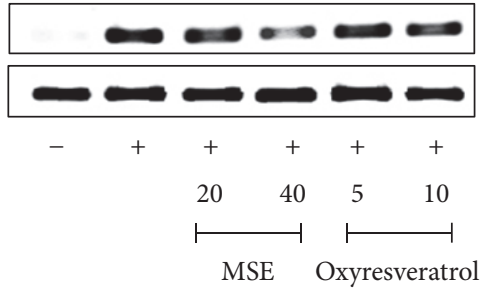

(a)

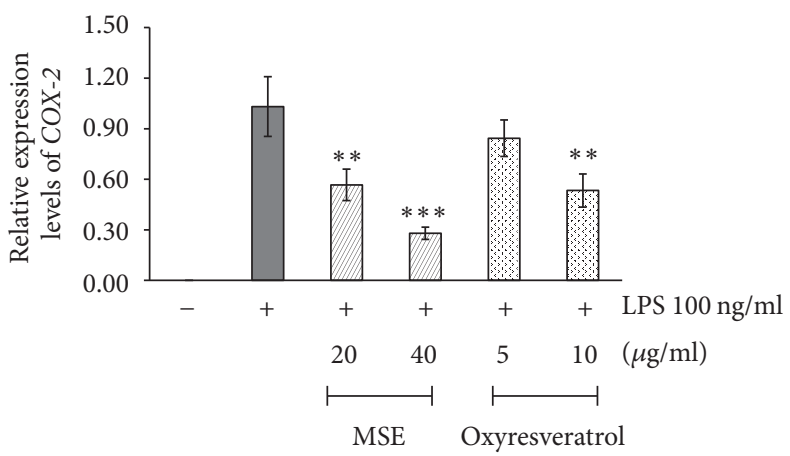

(b)

FIGURE 6: The effects of MSE and oxyresveratrol on the expression of COX-2 mRNA in RAW 264.7 cells. The untreated cells were used as a negative control and the cells treated with only $100 \mathrm{ng} / \mathrm{ml}$ LPS served as a positive control. (a) RT-PCR analysis for detection of COX-2 mRNA expression in LPS-stimulated RAW 264.7 cells which were pretreated with MSE at the concentrations of 20 and $40 \mu \mathrm{g} / \mathrm{ml}$ or oxyresveratrol at the concentrations of 5 and $10 \mu \mathrm{g} / \mathrm{ml}$ for $6 \mathrm{~h}$. (b) The relative expression of COX-2 mRNA compared to $\beta$-actin. The data were represented as means $\pm \mathrm{SD}$ of three independent experiments. The means marked with $* *, * * *$ are significantly different $(P<0.005)$ and $(P<0.001)$, respectively, from that of the cells treated with only LPS.

stems on LPS-induced RAW 264.7 cells. The investigation found that concentrations at 20 and $40 \mu \mathrm{g} / \mathrm{ml}$ had no toxic effect. The results suggest that the stem extract mediates its anti-inflammatory activities through the inhibition of iNOS, $\mathrm{NO}$, and COX-2 production. Further studies are necessary to fully define the precise mechanisms involved.

\section{Conflicts of Interest}

The authors declare that there are no conflicts of interest regarding the publication of this article.

\section{Acknowledgments}

The authors would like to acknowledge the financial support from the yearly budget of Naresuan University, Thailand (R2555B069 and R2558B053), the Center for Innovation in Chemistry (PERCH-CIC), and National Research Council of Thailand Graduate Student Scholarship (2014). They express special gratitude towards the Queen Sirikit Sericulture Center (Tak) for the supply of plant materials and to Mr. Chein Yhirayha for the purification of the oxyresveratrol. Many thanks are due to Mr. Roy Morien of the Naresuan University Language Centre for his editing assistance and advice on English expression in this manuscript.

\section{References}

[1] E. W.-C. Chan, P.-Y. Lye, and S.-K. Wong, "Phytochemistry, pharmacology, and clinical trials of Morus alba," Chinese Journal of Natural Medicines, vol. 14, no. 1, pp. 17-30, 2016.

[2] K.-O. Chung, B.-Y. Kim, M.-H. Lee et al., "In-vitro and in-vivo anti-inflammatory effect of oxyresveratrol from Morus alba L," Journal of Pharmacy and Pharmacology, vol. 55, no. 12, pp. 16951700, 2003.

[3] H. S. Lee, D. H. Kim, J. E. Hong, J.-Y. Lee, and E. J. Kim, "Oxyresveratrol suppresses lipopolysaccharide-induced inflammatory responses in murine macrophages," Human and Experimental Toxicology, vol. 34, no. 8, pp. 808-818, 2015.

[4] P. Thongsuk, In vitro and clinical study of mulberry extract for skin whitening product [M.S. thesis], Naresuan University, Phitsanulok, Thailand, 2007.

[5] D. Laveti, M. Kumar, and R. Hemalatha, "Anti-inflammatory treatments for chronic diseases: a review," Inflammation \& Allergy-Drug Targets, vol. 12, no. 5, pp. 349-361, 2013.

[6] Y.-C. Chen, Y.-J. Tien, C.-H. Chen et al., "Morus alba and active compound oxyresveratrol exert anti-inflammatory activity via inhibition of leukocyte migration involving MEK/ERK signaling," BMC Complementary and Alternative Medicine, vol. 13, no. 1, pp. 45-55, 2013.

[7] C. Yhirayha, Formulation and skin penetration study of lyotropic liquid crystal incorporating mulberry stem (Morus alba L.) extract [M.S. thesis], Naresuan University, Phitsanulok, Thailand, 2013.

[8] M. Pudla, K. Limposuwan, and P. Utaisincharoen, "Burkholderia pseudomallei-Induced expression of a negative regulator, sterile- $\alpha$ and Armadillo motif-containing protein, in mouse macrophages: a possible mechanism for suppression of the MyD88-independent pathway," Infection and Immunity, vol. 79, no. 7, pp. 2921-2927, 2011.

[9] N. Soonthornsit and T. Pitaksuteepong, "Microemulsion formulation containing mulberry stem extract," in Proceedings of the 38th Congress on Science and Technology of Thailand, 6 pages, Chiang Mai, Thailand, October 2012.

[10] C. H. Hong, S. K. Hur, O.-J. Oh, S. S. Kim, K. A. Nam, and S. K. Lee, "Evaluation of natural products on inhibition of inducible cyclooxygenase (COX-2) and nitric oxide synthase (iNOS) in cultured mouse macrophage cells," Journal of Ethnopharmacology, vol. 83, no. 1-2, pp. 153-159, 2002.

[11] E.-M. Choi and J.-K. Hwang, "Effects of Morus alba leaf extract on the production of nitric oxide, prostaglandin $\mathrm{E}_{2}$ and cytokines in RAW264.7 macrophages," Fitoterapia, vol. 76, no. 7-8, pp. 608-613, 2005.

[12] Z.-G. Yang, K. Matsuzaki, S. Takamatsu, and S. Kitanaka, "Inhibitory effects of constituents from Morus alba var. multicaulis on Differentiation of 3T3-L1 cells and nitric Oxide 
Production in RAW264.7 Cells," Molecules, vol. 16, no. 7, pp. 6010-6022, 2011.

[13] H. J. Lim, H.-G. Jin, E.-R. Woo, S. K. Lee, and H. P. Kim, “The root barks of Morus alba and the flavonoid constituents inhibit airway inflammation," Journal of Ethnopharmacology, vol. 149, no. 1, pp. 169-175, 2013.

[14] E. Park, S.-M. Lee, J. E. Lee, and J.-H. Kim, "Anti-inflammatory activity of mulberry leaf extract through inhibition of NF- $\kappa \mathrm{B}$," Journal of Functional Foods, vol. 5, no. 1, pp. 178-186, 2013.

[15] H. Zelova, Z. Hanakova, Z. Cermákova et al., "Evaluation of anti-inflammatory activity of prenylated substances isolated from Morus alba and Morus nigra," Journal of Natural Products, vol. 77, no. 6, pp. 1297-1303, 2014.

[16] A. Abate, S. Oberle, and H. Schröder, "Lipopolysaccharideinduced expression of cyclooxygenase- 2 in mouse macrophages is inhibited by chloromethylketones and a direct inhibitor of NF- $\kappa \mathrm{B}$ translocation," Prostaglandins and Other Lipid Mediators, vol. 56, no. 5-6, pp. 277-290, 1998.

[17] S.-H. Lee, C.-H. Kwak, S.-K. Lee et al., "Anti-inflammatory effect of ascochlorin in lps-stimulated raw 264.7 macrophage cells is accompanied with the down-regulation of iNOS, COX-2 and proinflammatory cytokines through NF- $\kappa \mathrm{B}, \mathrm{ERK} 1 / 2$, and p38 signaling pathway," Journal of Cellular Biochemistry, vol. 117, no. 4, pp. 978-987, 2016.

[18] L. Parente, "Pros and Cons of Selective Inhibition of COX-2 versus Dual Lipoxygenase/COX Inhibition: Is Two Better than One?" The Journal of Rheumatology, vol. 28, no. 11, pp. 23752382, 2001.

[19] U. N. Das, "Cyclooxygenase (COX), lipoxygenase (LO) pathways and generation of lipoxins, resolvins, protections and maresins," in Molecular Basis of Health and Disease, N. D. Undurti, Ed., vol. 4, pp. 59-61, Springer Science Business Media BV, Dordrecht, Holland, 2010.

[20] Y. Bellik, L. Boukraa, H. A. Alzahrani et al., "Molecular mechanism underlying anti-inflammatory and anti-allergic activities of phytochemicals: an update," Molecules, vol. 18, no. 1, pp. 322353, 2012.

[21] C. Rivière, S. Krisa, L. Péchamat et al., "Polyphenols from the stems of Morus alba and their inhibitory activity against nitric oxide production by lipopolysaccharide-activated microglia," Fitoterapia, vol. 97, pp. 253-260, 2014.

[22] S. Das and D. K. Das, "Anti-inflammatory responses of resveratrol," Inflammation and Allergy-Drug Targets, vol. 6, no. 3, pp. 168-173, 2007. 


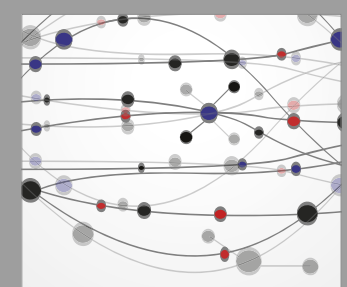

The Scientific World Journal
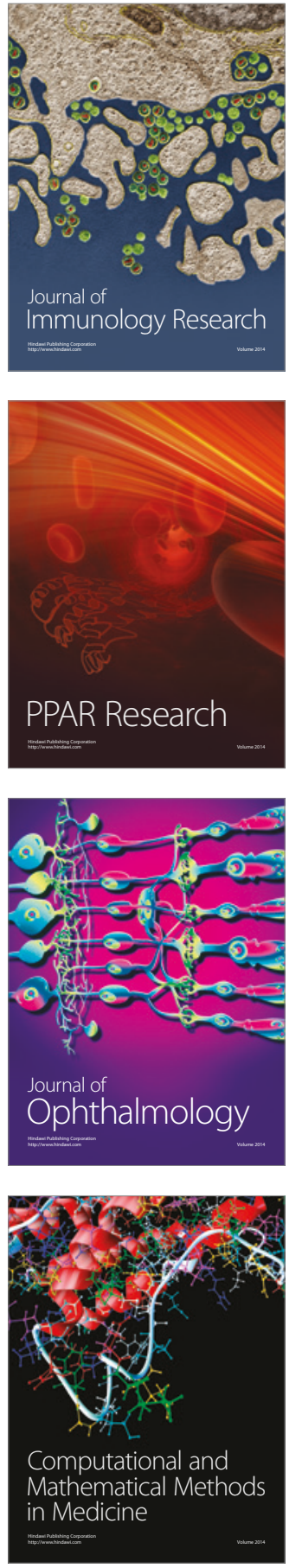

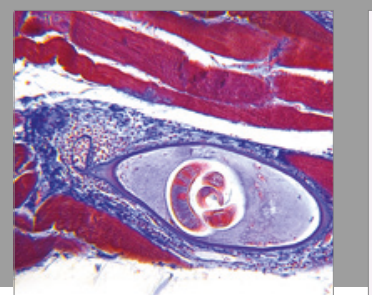

Gastroenterology Research and Practice
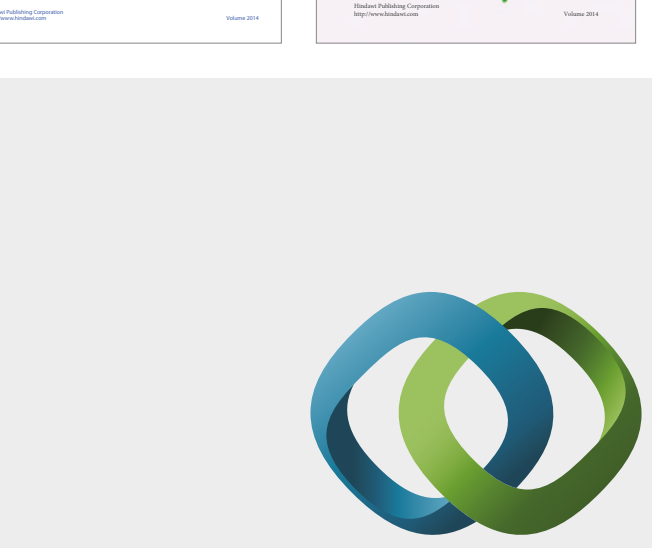

\section{Hindawi}

Submit your manuscripts at

https://www.hindawi.com
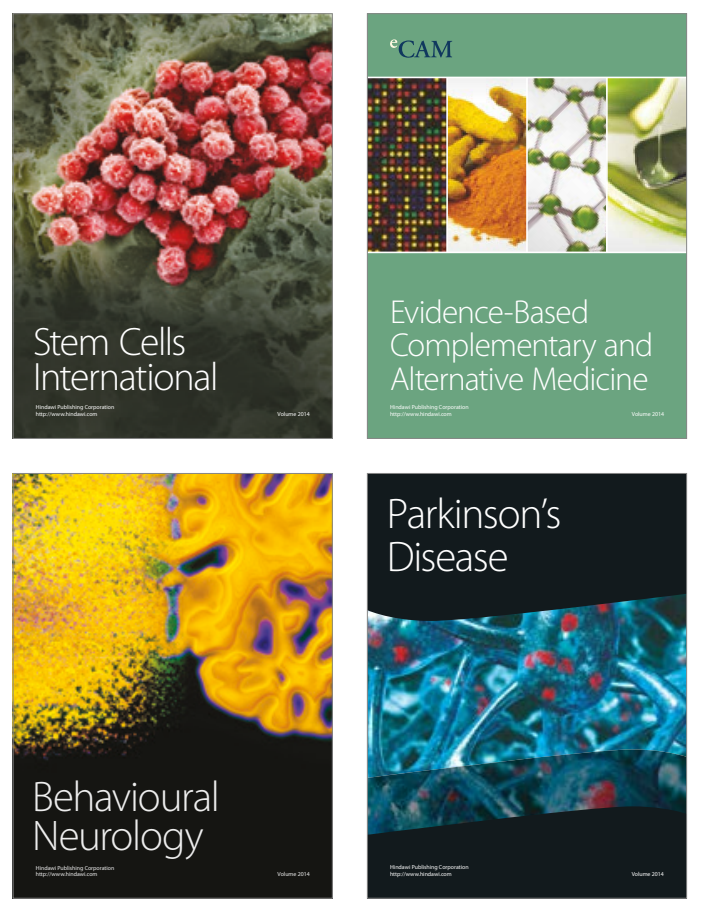
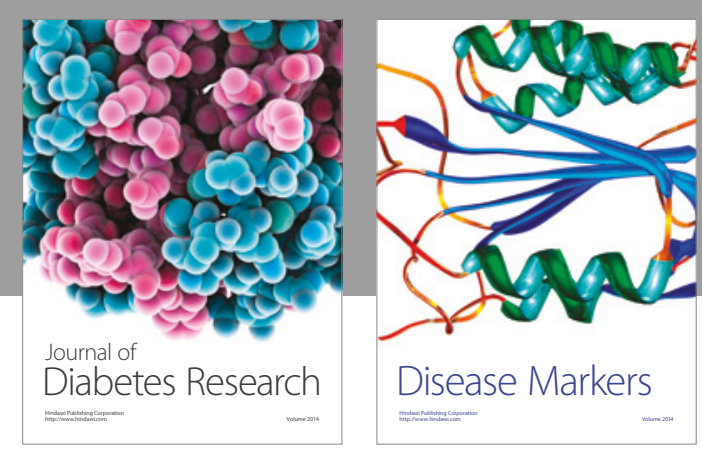

Disease Markers
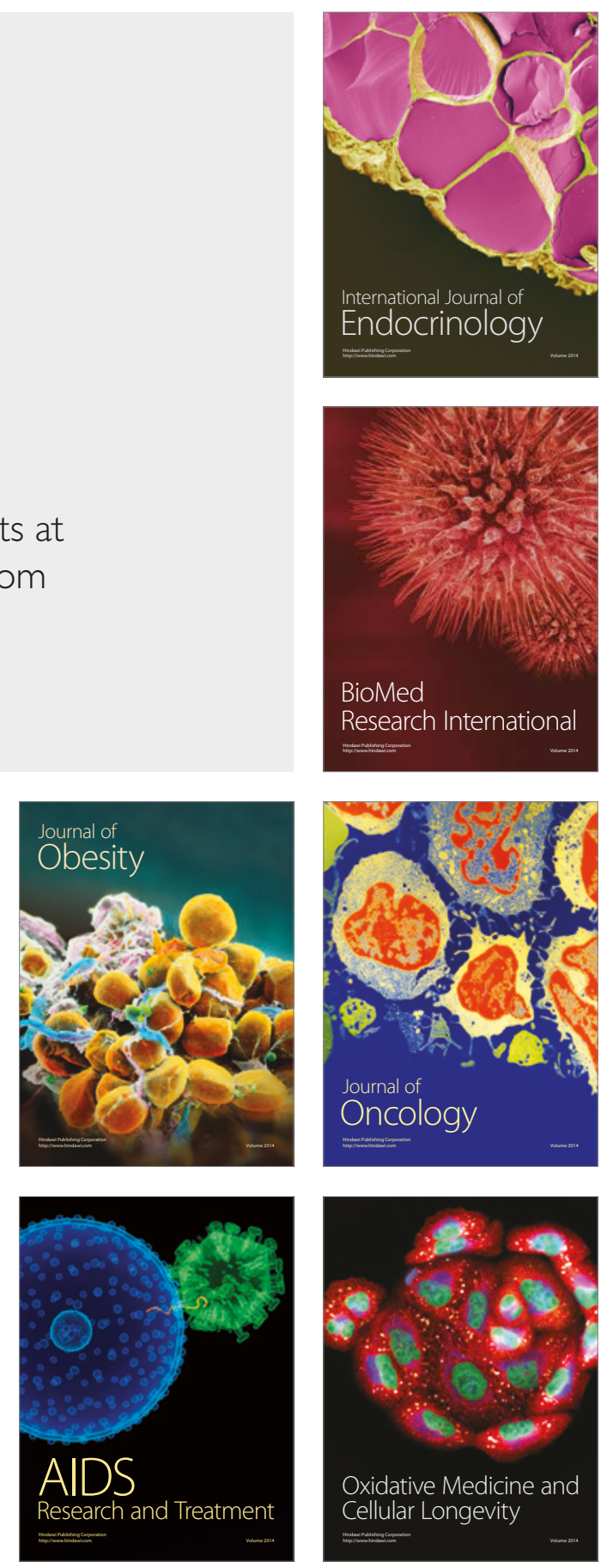